\title{
Kilenc erős tételmondat Közép-Európáról és Magyarországról Csaba László könyve kapcsán
}

\author{
Csaba László: Válság, gazdaság, világ. Adalék Közép-Európa \\ három évtizedes gazdaságtörténetéhez (1988-2018). Éghajlat \\ Könyvkiadó, Budapest, 2018, 256 o.
}

Alighanem tudományos pályájának legfontosabb könyvét jelentette meg Csaba László. Az Éghajlat Könyvkiadó által gondozott elegáns, kemény kötésü, 250 oldal terjedelmű írás alcíme szerint a könyv „csak” adalékul kíván szolgálni Közép-Európa 1988 és 2018 közötti gazdaságtörténetéhez. Valójában azonban ennél sokkal többet vállalt a szerző: gyermekeink és unokáink nemzedékének ad magyarázatot arra, hogy miként jutottunk „ide”. Ezt fejezi ki a - tulajdonképpen kettős értelmü - ajánlás is a könyv belső címlapján: „A Törpéknek, hogy Ők is tudják, hogyan jutottunk ide.” Az olvasó önkéntelenül is elgondolkodik, kik lehetnek azok a „Törpék”, akikre a szerző gondol. Adynál - például - ez a metafora mindig a kortársak selejtjére, a percemberkékre vonatkozik. Lehet, hogy itt is?

Miért érdemes ismételten foglalkozni ezzel a könyvvel? ${ }^{1}$ Azért, mert Csaba László könyve szembemegy a hazai mainstreammel. Nem is egy kérdésben, hanem sokban. De meggyőző érveket vonultat fel, amelyekkel érdemes röviden megismerkedni azoknak is, akiknek nincs idejük az egész könyv alapos átolvasására.

1. Közép-Európa számos országában, így Magyarországon, sőt még a minden szempontból előnyösebb helyzetü Kelet-Németországban is elmaradt a rendszerváltás csodája (39. o.). A második világháború kataklizmáját követő helyreállítás nem ismétlődött meg, jóllehet sokan azt gondolták (magamat is ideértve), hogy a szocialista tervgazdasági rendszer és az egypárti politikai diktatúra megszűnése legalább akkora vagy talán még nagyobb növekedési energiákat fog felszabadítani. Az EU-tagság sem járt olyan mértékủ gazdasági előnnyel és civilizációs hatással, ami a térség választóinak többségét lenyügözte volna (155. o.). Miközben ténylegesen harminc év alatt majdnem minden országban jelentős volt a gazdasági fejlődés, nőtt a nemzeti vagyon, emelkedett az életszínvonal, a javulás mértéke messze elmaradt a várakozásoktól,

\footnotetext{
${ }^{1}$ Folyóiratunk ez év márciusi számában már közöltünk egy recenziót Csaba László könyvéröl Botos Katalin tollából, Útépítés a világáramban címmel, de az lényegében két témakörre, az Európai Unió ügyeire és a bankszektor müködésére koncentrált. Ezért döntöttünk ezen recenzió megjelentetése mellett. (A szerk.)
}

A kézirat első változata 2019. június 5-én érkezett szerkesztőségünkbe.

DOI: http://dx.doi.org/10.18414/KSZ.2019.7-8.893 
a reményektől, valamint a kezdettől fogva befolyásos populista közvélemény-formálók ígéreteitől. Magyarországon már 2010 előtt is sokan - baloldali és jobboldali politikai érzületre alapozva - nagy hangerővel bírálták a rendszerváltozás első két évtizedének gazdasági teljesítményét, de az eredmények lebecsülése 2010 után egyre inkább elterjed állásponttá vált. ${ }^{2} \mathrm{~A}$ volt NDK kudarcát - mint tanulságos példát - aligha lehet túlértékelni. Csaba félig viccesen, de valójában mégiscsak komolyan írja, hogy az egykori Kelet-Németország mai területén még harminc évvel később sem tanultak meg elegen elitszinten futballozni (a Bundesliga I. osztályában általában nincs több mint két csapat keletről), de nincs élvonalbeli egyetemük vagy kutatóintézetük sem. Ezért ne legyünk meglepve, hogy Magyarország sem tud helytállni az élvonal versenyében!

2. A mából visszatekintve úgy tűnik, hogy a posztszocialista országok elemzői és az a hatalmas külföldi szakértői tábor, amely az átalakításban segédkezett, a kezdet kezdetétől fogva félreértette a fejlődést akadályozó körülmények lényegét. Csaba megismerteti a magyar olvasókkal az amerikai gazdaságtörténész, Deirde N. McCloskey megközelítését (McCloskey [2006-2016]), és egyúttal állást is foglal mellette. A fejlődés motorja hosszabb távon nem valamely materiális tényező - közgazdásznyelven a tőke $(K)$ és a munka $(L)$-, de nem is az intézmények minősége. Valójában az adott ország társadalmának értékrendje, politikai-etikai meggyőződése és az ezeken alapuló közbeszéd, a szavak ereje az, ami a döntéseket és a döntések nyomán a valóságot formálja. Ez magyarázza az angol, amerikai és ausztrál gazdaság tartós sikereit: azt, hogy az elvileg minden ország számára hozzáférhető tudásnál sokkal fontosabb a tudás hasznosulása.

Csaba McCloskey gondolatmenetét kiterjesztve meggyőzően mutatja be, hogy mindez nemcsak a posztszocialista átalakulásra érvényes, de a mi térségünk szempontjából meghatározó Európai Unió történéseire is. Tíz évvel a nemzetközi pénzügyi válság után, 2018 végére a képzeletbeli Rubicon naposabb oldalára kerültek azok az országok, amelyek komolyan vették, hogy piackonform (Csaba szóhasználatával: ortodox-neoliberális, 88. o.) költségvetési és szabályozási reformok nélkül az euróra való áttérés viszszafelé fog elsülni. A folyó másik oldalára pedig azok az országok kerültek, amelynek irányítói nem mertek elköteleződni a szerkezeti reformok mellett (például Görögország vagy Olaszország). ${ }^{3}$ Ezek az országok ma is nagy bajban vannak, időről időre reális veszélynek látszik, hogy előbb vagy utóbb kizuhannak az euróövezetből. Vagyis sok tény szól amellett, hogy az Európai Unión belül az igazi szakadék nem a régi és az új tagállamok között húzódik, mint ahogyan azt a magyar kormány gondolta a visegrádi négyek életre hívásakor (és gondolja ma is), hanem az északi és a déli tagállamok között.

\footnotetext{
${ }^{2}$ Tomka Béla könyvére hivatkozva (Tomka [2011]) Csaba felhívja a figyelmet arra, hogy ilyenfajta alulértékelésre vagy túlértékelésre az elmúlt száz évben több példa is volt. A művelt közbeszéd begyöpösödött narratívái évtizedek óta arra épülnek, hogy túlbecsülik a kiegyezés utáni időszak gazdasági növekedését, ugyanakkor alulértékelik a két világháború közötti korszak gazdasági teljesítményét. Lásd még a két említett periódus növekedési adatairól Mihályi [2019] tanulmányát is.

${ }^{3}$ Ezt a dilemmát egészen konkrét formában már 2007-ben megfogalmazta Jean-Claude Juncker (még nem az Európai Bizottság elnökeként, hanem Luxemburg éppen akkortájt megbukott miniszterelnökeként): „Tudjuk, hogy mit kellene tenni, csak azt nem tudjuk, hogy miként tudnánk választást nyerni, ha mindezt megtesszük."
} 
Mindkét országcsoport értékvezérelt, vagyis a kormányok döntéseit a társadalmi elvárások és a leginkább elterjedt gondolkodási sémák határozzák meg (194. o.).

Györffy [2015] magyar-lett összehasonlítására hivatkozva Csaba még azt a kemény állítást is megfogalmazza, hogy az erős társadalmi és politikai elkötelezettség a reformok mellett még gyenge intézményi müködés esetén is eredményesebb, mint a mégoly kiterjedt intézményi fejlödés, ha hiányzik a politikai akarat, a szakmai egyetértés és a politikai bátorság. Ezt a gondolatmenetet visszafelé alkalmazva nem nehéz belátni, hogy az 1989-et követő három-négy évben - zömében az Antall-kormány idején - a magyar gazdaság nem azért került a rendszerváltó országok versenyében az élre, mert nálunk sikerült az intézményeket leggyorsabban átalakítani, illetve a semmiből kifejleszteni, hanem azért, mert a rendszerváltó értelmiség és a politikai elit viszonylag egységes, elkötelezett és bátor volt. Antall József tehát jó okkal nevezte saját kormányát „kamikazekormánynak”. Antall sejtette, tudta, hogy a következő választásokat az MDF nem fogja megnyerni, ennek ellenére - hogy egy régebbi kor epigrammáját idézzük - „megcselekedte, amit megkövetelt a haza”.

Magyarország későbbi története is azt mutatja, hogy - bár sok múlik az anyagi feltételeken, a politikusok ügyességén - mindennél fontosabb, hogy egy-egy ország politikai elitje és közvéleménye hova pozicionálja önmagát (78. o.). Ezen eszmék között Közép-Európában fontos szerepet játszott, hogy az elit az 1990 utáni időszakban őszintén feladatának és erkölcsi kötelezettségének tartotta a nyugati világhoz, az európai centrumhoz való felzárkózást, az Európai Unió írott és íratlan normáinak átvételét. 2010 után ezen a téren döntő változások történtek. Számos dimenziót tekintve éppen Magyarország fordult el ettől az iránytól elöször. Ez a „keleti nyitás” gondolatának valódi tartalma: az orosz és a kínai minta másolása.

3. Fontos eredménye Csaba könyvének, hogy meggyőző módon foglal állást az úgynevezett sequencing-vitában, vagyis abban a kérdésben, hogy a posztszocialista, rendszerváltó reformok milyen sorrendben hajtandók végre. A sikeres régi és új példákra (az erhardi Németország, a balcerowiczi Lengyelország, Magyarország, a balti országok és újabban Kína) hivatkozva, a mából visszatekintve a terápia következő sorrendje látszik helyesnek. Első lépés az árak felszabadítása, majd pedig az infláció megfékezése, a stabilizáció. A második lépés a liberalizáció, a versenykorlátozó jogszabályok és elöírások pénzügyi természetű korlátokkal való felváltása. Az átalakulás harmadik eleme az intézményépités, amelyröl ma már tudjuk (de csak a 2008-as pénzügyi válság óta), hogy ez soha nem ér véget. A privatizáció az átalakulás negyedik eleme, ${ }^{4}$ amihez a jelen sorok írója a maga véleményeként azt is hozzáteszi, hogy ez a folyamat sem olyan, mint amely öt-tíz év alatt lezárható lenne. A globalizáció sokféle és szerteágazó következményei világossá tették, hogy a fejlett piacgazdaságokban is, meg az elmaradott, de fejlödő országokban is olyan területeken vált megkerülhetetlenné az állami feladatok részleges privatizációja,

\footnotetext{
${ }^{4}$ Ha valaki keresi a formáját annak, hogy a sorrendet miként lehet könnyen és biztosan megjegyezni, Csaba segít ebben: az angol SLIP szót ajánlja, amely angolul is és magyarul is a négy lépés kezdöbetűiből áll össze (32. o.).
} 
amelyekre korábban még a liberális közgazdászok többsége sem gondolt (például légi közlekedés, vasút, nyugdíjrendszer, egészségügy, oktatás).

4. A nemzetközi pénzügyi válság nyomán 2008-ban kiderült, hogy nagy árat kell Magyarországnak azért fizetni, mert a reformlendület csak addig tartott, amíg bekerült az EU-ba. A továbbhaladás fö akadálya az volt, hogy a politikai elit megosztott volt a globalizált világgazdaság logikája által diktált lépések szükségességének tekintetében. Nemcsak a politikai bal- és jobboldal között húzódott mély árok, de a két politikai táboron belül is nagy volt a megosztottság. Ebben a perspektívátlan helyzetben a magyar elit egésze számára a kézenfekvő stratégia a carpe diem volt (122. o.), ami - egészen 2016-ig - a jövőt szolgáló anyagi beruházások riasztóan alacsony arányában is megmutatkozott.

5. Csaba erösen vitatja az 1990-es évek óta Közép-Európában elterjedt útfüggőség (path dependency) koncepcióját. Két fontos ellenpéldája van: Oroszország és Németország eltérő fejlődési pályája. A nagyhatalmi múlt mindkét országban jelen volt. Oroszország - mint a Szovjetunió utódállama - máig nem tudott letérni erről a pályáról, míg Németországban a nagyhatalmi gőgnek már rég nyoma sincs. Angela Merkel Németországa a multikulturalizmus és a globális integráció hazája lett, Oroszország viszont egy rövid együttműködési időszak után agresszívvá vált a világpolitika több színterén is. Nagyon érdekes Lengyelország pályája is. A kilátástalan, reménytelen vergődés fogalmával egyenértékü polnische Wirtschaft (magyarán zsibvásár) helyzetéből kitörve 2010-re Lengyelország Európa egyik legjobban teljesítő országa lett - egyebek mellett Magyarországot is megelőzve. S tette ezt úgy, hogy a kormányzat „csak” annyit csinált, hogy nem vállalkozott semmiféle „nagy ugrásra”, sehol ki nem próbált, unortodox ötletek kipróbálására (116. o.). Nagyon hosszú távon ez sem elégséges a felzárkózási folyamat fenntartásához, de mégis sokkal jobb, mint a teljesítmény-visszaesés.

6. Ha a posztszocialista országok tágabb körét nézzük - vagyis túllépünk Közép-Európa határain -, akkor egyértelmü, hogy Oroszország sikertelen átalakítása kihatott az összes többi országra is. Ebben az esetben a kiinduló helyzet valóban különösen kedvezőtlen volt. Jelcin egy olyan országot vett át, amely 1990/1991-ben az éhínség határán volt. Ilyen körülmények között illúziónak bizonyult a kor moszkvai értelmiségének (ideértve Mihail Gorbacsovot is) az a szándéka, hogy Oroszország váljon „normális országgá”, lemondva a birodalmi aspirációkról és arról az évszázados meggyőződésről, hogy Oroszország méretei és történelme miatt különleges, rá más törvényszerűségek vonatkoznak. Ezzel szemben Csaba elmagyarázza, hogy a különlegesség mítosza nemcsak az olyan nagy országok esetében elterjedt, mint az Egyesült Államok, Kína vagy éppen Törökország, de Magyarországon is máig él az „Ugocsa non coronat” és az „Extra Hungariam non est vita" tévképzete. És ebböl mindig csak bajok származtak.

Visszatérve az orosz példára: el kell ismerni, hogy az éhség nagy úr. Végzetesen rossz gazdasági körülmények között nehéz távlatos reformokat végrehajtani, mert a mindenkori vezetök okkal félnek attól, hogy egy népfelkelés során lámpavason fogják végezni. Putyin elnök kezdetben megpróbált a NATO-ra és az Európai Unióra 
támaszkodva külső forrásokhoz jutni, de Oroszország történelmi balszerencséjére az átmenetileg megemelkedett olaj- és gázárak az orosz társadalom elitjét arra a következtetésre sarkallták, hogy saját erőből - vagyis a külföldi tőke importjának drasztikus korlátozása mellett is - fel tudják építeni a versenyképes posztszocialista piacgazdaságot. Pestiesen szólva: ez nagyon nem jött össze! De nem egyszerű tévedésről volt szó. A rendszerváltás pillanatában sem az orosz politikai elit, sem a közvélemény nem érzékelte a helyzet súlyosságát. Nem arról van szó, hogy ne szenvedett volna a társadalom többsége, de még az elit tagjai is az áruhiánytól. Ám a közhiedelem az volt, hogy ez az élet természetes velejárója, a kapitalista világ árubősége csupán látszat. Oroszországban meglehetősen általános volt az a vélekedés, hogy valamiféle harmadikutas megoldást kigondolva, lehetséges a jólét szocialista módon is.

7. Oroszország helyzetének elemzése logikai és módszertani szempontból nem választható el Kína vizsgálatától. Csaba meggyőzően érvel amellett, hogy az eddig eltelt három évtizedben a döntő különbség a két ország reformstratégiája között az volt, hogy a Kínai Kommunista Párt Teng Hsziao-ping reformjainak szellemében 1. idejekorán megnyitotta a piacokat a külföldi tőke előtt, 2. ezzel egy időben nagy erőket mozgósított a kínai gazdaság külföldi offenzívájának anyagi megtámasztására. Az FDI-szakirodalomból részletesen ismert minden irányban ható átgyürüző hatások (forward és backward linkages) Kínában a pozitív technológiai változások sorát nyitották meg, miközben az orosz feldolgozóipar saját erejéből szinte semmire sem jutott. Ehhez hadd tegyük hozzá: a Világbank legfrissebb, 2017-es adatai szerint Kína áruexportjának 94 százaléka (!) feldolgozóipari termék, míg a megfelelő orosz adat csupán 22 százalék. És egy másik fontos adat: Kína két évtized alatt mintegy 200 kínai céget vitt ki az amerikai tőzsdékre, többet, mint bármely más ország az Egyesült Államokon kívül.

8. A kínai és az orosz példa szembeállítása még egy fontos ponton visszatér Csaba fejtegetései során (244. o.). Az elmúlt 10-15 évben számos kelet-európai országban, de ezen túlmenően Törökországban, Indiában és egy sor arab országban is tekintélyelvü, autokrata rendszerek épültek ki arra a feltételezésre alapozva, hogy az erőskezü központi politika és a kormányzat által tudatosan irányított piaci fejlődés hibridje hosszú távon alkalmas lesz a gazdasági növekedés felgyorsítására. Meggyőzőnek tủnik azonban Csabának az a sejtése, hogy ez a kombináció csak azokban a kelet-ázsiai társadalmakban életképes, ahol még él a teljesítményelvü konfuciánus és sintoista hagyomány - mindenütt másutt ez a fajta hibrid rendszer előbb vagy utóbb kudarcot vall.

9. Csaba szerint 2012-re datálható a Magyarország szempontjából második fontos korszakhatár. Ekkor vált bizonyossá - vagy fogalmazzunk mi óvatosabban: belátható időn belül bizonyossá - a kétsebességes Európa létrejötte. Az euróövezeten kívül rekedtek a másodosztályú tagok (Magyarország is), hiszen még szavazati, sőt konzultációs joga sincsen az Unió egészét érintő legnagyobb horderejü pénzügyi döntésekben (168. o.). Az EU háborút nem tud ugyan indítani az euróövezeten kívül rekedt tagállamok szavazata nélkül, de ennek - a szuverenitás látszata ellenére - nem sok jelentősége van. Mint könyvének egy másik helyén (67. o.) Csaba 
okkal figyelmezteti a Brüsszel ellen szuverenitási harcot folytató politika híveit és elfogadóit: valójában a háború vagy béke kérdése nem az EU-ban, hanem a NATOban dől el, merthogy a parancsnoki struktúra és a közös logisztika felépítése miatt a katonai hadműveletek megindítása sokkal egyértelmübb, mint az EU esetében. ${ }^{5}$

Csaba könyvében szinte megszámolhatatlanul sok olyan számadat szerepel, amely meg kell, hogy rettentse a hozzáértő olvasókat. Nagy bajok előtt állunk. Sejtésem szerint közel egy évvel a könyv megjelenése után a magyar gazdaság makroszintü termelékenységi adatai adnak a legtöbb okot az aggodalomra. Mint a szerző Kónya [2017] alapján írja (224-225. o.): elgondolkodtató, hogy immár több mint 800 ezerrel többen állítják elő ugyanazt a dollármennyiség/GDP-t, mint egy évtizeddel korábban. ${ }^{6}$ Vagyis, hiába dolgozunk egyre többen és egyre többet, egész éves munkánk a világpiacon egyre kevesebbet ér.

\section{Hivatkozások}

GYőRFFY DóRA [2015]: Austerity and growth in central and eastern Europe: understanding the link through contrasting crisis management in Hungary and Latvia. Post-Communist Economics, Vol. 27. No. 2. 129-152. o. ttps://doi.org/10.1080/14631377.2015.1026682.

KóNYA IsTvÁn [2017]: A magyar növekedésről - egy régimódi megközelítés. Közgazdasági Szemle, 64. évf. 9. sz. 915-929. o. https://doi.org/10.18414/ksz.2017.9.915.

McCloskey, D. N. [2006-2016]: The Bourgois Era. I-III. The Chicago University Press, Chicago.

MinÁLYi PÉTer [2019]: Miként lett „bukott állam” Magyarország, és ki volt a felelös érte? (Az I. világháború 100 éves perspektívából. Köz-Gazdaság, 14. évf. 1. sz. 252-311. o. http://kozgazdasagtudomany.uni-corvinus.hu/fileadmin/user_upload/hu/kozgazdasag tudomanyi_kar/files/Koz_gazdasag/XIV._evfolyam_1.szam_2019._marcius/HU_ Mihalyi_Koz_Gazdasag_2019_honlapra.pdf.

Томка BéLA [2011]: Gazdasági növekedés, fogyasztás és életminőség Magyarország nemzetközi összehasonlításában. Akadémiai Kiadó, Budapest.

Mihályi Péter

\footnotetext{
${ }^{5}$ Jó példa erre - és Csaba idézi is -, hogy már 1999-ben is az történt, hogy a Szerbia és Montenegró elleni NATO légi csapások logisztikai bázisaként szükségessé vált a magyar területeknek a szövetségesek részére történő átengedése, a taszári amerikai támaszpont létesítése - vagyis belekeveredtünk a határaink közvetlen közelében zajló délszláv háborúba.

${ }^{6}$ A frissebb adatok tükrében még rosszabb a helyzet. Saját számításaim szerint Magyarország dollárban kifejezett GDP-je 2008-ban 158 milliárd dollár volt, míg 2018-ban csak 147 milliárd - miközben a foglalkoztatottság folyamatosan nőtt.
}

Mihályi Péter egyetemi tanár, Budapesti Corvinus Egyetem Makroökonómia Tanszék. 